\title{
A proposal of conceptual model for Pertuso Spring discharge evaluation in the Upper Valley of Aniene River
}

\section{Proposta di modello concettuale per la stima della portata della sorgente Pertuso nell'Alta Valle del fiume Aniene}

\author{
Giuseppe Sappa, Flavia Ferranti, Francesco Maria De Filippi
}

\begin{abstract}
Riassunto: Il bacino idrogeologico della parte alta del Fiume Aniene appartiene ad un grande acquifero carsico, che interagisce con il fiume e rappresenta la più importante risorsa idrica nella parte sud-orientale della Regione Lazio (Italia Centrale) usata per approvvigionamento potabile, agricolo e idroelettrico. Il presente lavoro fornisce i dati idrogeochimici e alcune loro interpretazioni per una sorgente e 2 sezioni di misura del Fiume Aniene, monitorate da luglio 2014 a dicembre 2015 nell'Alta Valle del Fiume Aniene. Lo scopo principale è stato quello di definire le vie di deflusso delle acque sotterranee e i processi idrogeochimici che governano le interazioni tra acque sotterranee e superficiali in questa zona. Questo articolo è perciò il risultato di attività eseguite per il piano di monitoraggio ambientale nell'ambito del progetto di captazione della Sorgente Pertuso, che sarà sfruttata per rifornire un'importante rete idrica nella zona Sud di Roma. Sono state analizzate le misure di portata e i dati idrogeochimici al fine di sviluppare un modello concettuale
\end{abstract}

Parole chiave: acquifero, carsismo, modellazione idrogeochimica, monitoraggio, tracciante ambientale.

Keywords: : aquifer, karst, hydrogeochemical modelling, monitoring, environmental tracer.

Giuseppe SAPPA, 辛=”

Department of Civil, Building and Environmental Engineering Sapienza University of Rome

via Eudossiana 18, 00184, Rome, Italy

Tel: +39.06.44585010 - Fax: +39.06.233239345

giuseppe.sappa@uniromal.it

Flavia FERRANTI, Francesco Maria DE FILIPPI

Department of Civil, Building and Environmental Engineering

Sapienza University of Rome

via Eudossiana 18, 00184, Rome, Italy

Ricevuto: 24 giugno 2016/ Accettato: 14 settembre 2016 Pubblicato online: 3 ottobre 2016

This is an open access article under the CC BY-NC-ND license: http://creativecommons.org/licenses/by-nc-nd/4.0/

(C) Associazione Acque Sotterranee 2016 di interazione tra fiume e acquifero, con l'obiettivo di raggiungere un corretto grado di gestione e protezione di questo importante sistema idrogeologico. Tutti i campioni d'acqua sono del tipo $\mathrm{Ca}-\mathrm{HCO}_{3}$ (bicarbonato-calcica). La modellazione geochimica e il calcolo dell'indice di saturazione per i campioni di acqua mostrano che la chimica delle acque sotterranee e superficiali nell'area di studio risente dell'interazione con i minerali carbonatici. Tutti i campioni di acqua sotterranea risultano sottosaturi rispetto alla calcite e alla dolomite, tuttavia alcuni campioni del Fiume Aniene sono saturi rispetto alla dolomite. Lanalisi dei rapporti $\mathrm{Mg}^{2+} / \mathrm{Ca}^{2+}$ indica che la dissoluzione dei minerali carbonatici gioca un ruolo significativo nella chimica delle acque sotterranee e superficiali, dipendendo dai processi idrogeologici che controllano il tempo di residenza delle acque sotterranee e gli equilibri chimici nell'acquifero.

Abstract: The Upper Aniene River basin is part of a large karst aquifer, which interacts with the river, and represents the most important water resource in the southeast part of Latium Region, Central Italy, used for drinking, agriculture and bydroelectric supplies. This work provides bydrogeochemical data and their interpretations for 1 spring and 2 cross section of Aniene River, monitored from July 2014 to December 2015, in the Upper Valley of Aniene River, to identify flow paths and bydrogeochemical processes governing groundwater-surface water interactions in this region. These activities deal with the Environmental Monitoring Plan made for the catchment work project of the Pertuso Spring, in the Upper Valley of Aniene River, which is going to be exploited to supply an important drinking water network in the South part of Rome district. Discharge measurements and bydrogeochemical data were analyzed to develop a conceptual model of aquifer-river interaction, with the aim of achieving proper management and protection of this important hydrogeological system. All groundwater samples are characterized as $\mathrm{Ca}-\mathrm{HCO}_{3}$ type. Geochemical modeling and saturation index computation of the water samples show that groundwater and surface water chemistry in the study area was evolved through the interaction with carbonate minerals. All groundwater samples were undersaturated with respect to calcite and dolomite, however some of the Aniene River samples were saturated with respect to dolomite. The analysis of $\mathrm{Mg}^{2+} / \mathrm{Ca}^{2+}$ ratios indicates that the dissolution of carbonate minerals is important for groundwater and surface water chemistry, depending on the bydrological processes, which control the groundwater residence time and chemical equilibria in the aquifer. 


\section{Introduction}

Most of groundwater in the southeast part of Latium Region, as in the whole Apennine Mountains chain, is stored in karst aquifers. Karst groundwater depletion is mostly due to the increasing of anthropogenic activities and the impacts of climate change (Guo et al. 2005, Sappa et al. 2013). Thus, groundwater exploitation in karst aquifers requires special management strategies to prevent their quality and quantity depletion and to support decision-making for water resources management (Sappa et al. 2013, Foster et al. 2013). In karst aquifers, the fast underground outflow in the saturated zone (White 1969, White 2002) is due to the heterogeneous distribution of permeability (Zwahlen 2004, Bakalowicz 2005), because there are many conduits and voids developed by the dissolution of carbonate minerals. Therefore, quantification of karst spring discharge and water budget formulation requires defining the karst network geometry, which is not, every time, measurable with reliability (Cherubini et al. 2008).

For this reason, environmental tracers are useful tools to provide information about groundwater flowpaths and residence times in karst aquifers without allowing for the specification of input locations and times (Clark and Fritz 1997, Mazor 2004).

Environmental tracers provide information about the flow and mixing processes of water coming from different sources (Guida et al. 2013). They are also useful to point out directions of groundwater flow and to determine origin and residence times of karst groundwater (Batiot et al. 2003, Sappa et al. 2015a, 2015b). Typical natural tracers are major ions, trace elements, dissolved organic carbon and water isotopes (Hunkeler and Mudry 2007, Leibundgut et al. 2009). Groundwater circulating in karst aquifer generally has great concentrations of Calcium and Magnesium as the result of bedrock weathering processes. Variations of $\mathrm{Ca}^{2+}$ and $\mathrm{Mg}^{2+}$ in groundwater are used very successfully as natural tracers in studies aiming to evaluate groundwater residence time within the karst aquifers (Batiot et al. 2003). The changes in $\mathrm{Ca}^{2+}$ and
$\mathrm{Mg}^{2+}$ concentration values mainly depend on the residence time of groundwater in karst systems, which are controlled by the volume and mechanism of recharge, the distance from the recharge area and the dissolution of carbonate minerals (Langmuir 1971, White 1988). The dissolution kinetics of Magnesium is longer than that of Calcium, so the increasing $\mathrm{Mg} 2+/ \mathrm{Ca} 2+$ ratio implies the saturation of water with calcite, highlighting long residence time and enhanced weathering along the groundwater flow paths (White 1988, Edmunds et al. 1987). The $\mathrm{Mg} 2+$ content in groundwater also depends on other parameters such as chemical and mineralogical purity of limestone and presence of dolomite within the rock masses they flow across (Mudarra and Andreo 2011). Nevertheless, the $\mathrm{Mg}^{2+}$ concentration values increase and hence $\mathrm{Mg}^{2+} / \mathrm{Ca}^{2+}$ ratio depend not only on the dissolution/ precipitation reaction of calcite and dolomite. In fact, a faster dissolution of dolomite may be due to an increasing in water temperature (Herman and White 1985). Thus, environmental tracers and hydrochemical investigation techniques provide much information about groundwater flow systems and the main hydrogeochemical processes affecting the composition of groundwater within the karst aquifers (Tooth and Fairchild 2003) and their interaction with surface water.

\section{Geological and hydrogeological setting}

Karst aquifer feeding Pertuso Spring is located in the Upper Valley of the Aniene River (Latium, Central Italy), along the SW boundary of the Simbruini Mountains, in the outcrop of Triassic-Cenozoic carbonate rocks, locally covered by fluvial and alluvial deposits and Quaternary sediments (Ventriglia 1990). The stratigraphic succession of dolomite, dolomitic limestone and limestone is distributed homogeneously in the Valley (Damiani 1990). Dolomite is the dominant lithofacies, characterized by white and gray crystalline dolomite, with some breccia levels. Over this geological formation, limestones and dolomites of Upper Cretaceous age are present, and their immersion is concordant with the Triassic dolomite (Damiani 1990). Karst springs are numerous along the first part of the

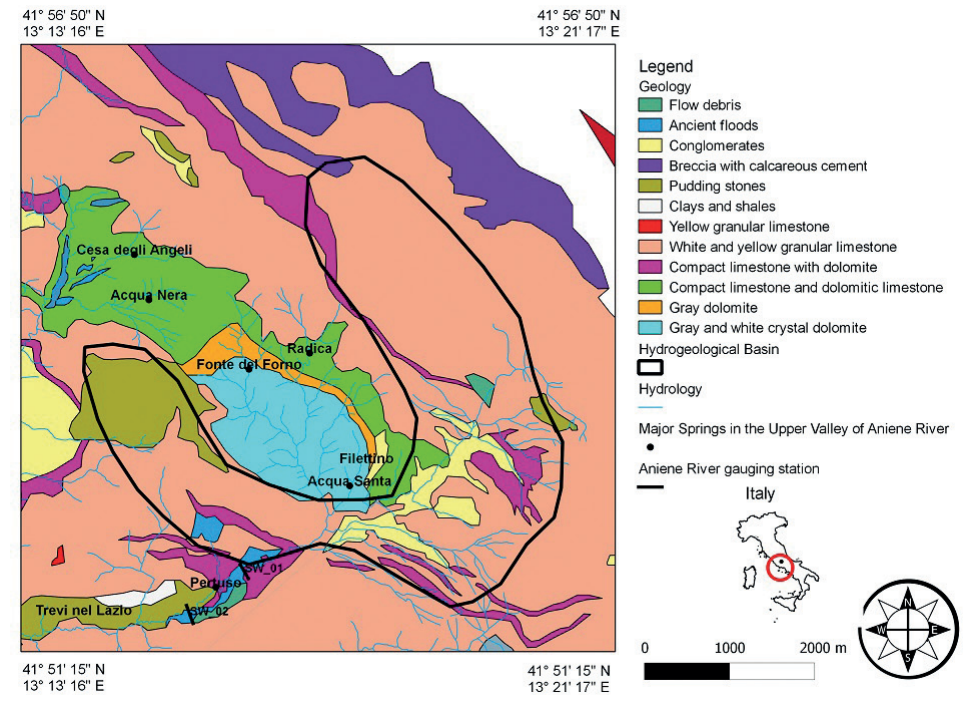

Fig. 1 - Simplified geological map of Pertuso Spring hydrogeological basin and location of Aniene River ganging sections.

Fig. 1 - Carta geologica semplificata del bacino idrogeologico della sorgente Pertuso e posizione delle stazioni di misura lungo il fiume Aniene. 
Aniene River and rise in the Triassic dolomitic formations (Fig.1).

This karst system is characterized by one main outlet, Pertuso Spring, and several springs which inflow into the Aniene River, at different points (Tab.1).

Due to their lower solubility and their ductility, dolomites are less fractured than limestone. As a consequence of it in the Aniene River Basin, almost all groundwater come out, where there is a limestone-dolomite contact (Ventriglia 1990) (Fig.1) and this latter one is below the former one.

Pertuso Spring (elevation of $698 \mathrm{~m}$ a.s.l.) is located between Filettino and Trevi nel Lazio (FR) and belongs to the Special Area of Conservation (SAC) of Aniene River Springs, established under Directive 92/43/EEC. This spring is the main outlet of this karst aquifer and comes out of alluvial sediments, covering a very thick layer made of Cretaceous limestone (Cipollari et al. 1995). The spring water is partially caught for hydroelectric and drinking supplies, whereas the remaining part directly flows into the Aniene River. The Pertuso Spring hydrogeological basin collects groundwater coming from a $50 \mathrm{~km}^{2}$ catchment area (Sappa and Ferranti 2014) bounded by the Triassic dolomite to the NE (Fig.1).

This aquifer is made, for the most part, of Cretaceous karst limestone. The base of the stratigraphic series is made of Upper Cretaceous carbonates, represented by the alternation of granular limestone and dolomites layers. Above these ones Quaternary fluvial and alluvial deposits lie, downward pudding and Miocene clay and shale (Ventriglia 1990). Rainfall is the primary source of recharge to this karst aquifer, feeded fastly through karst features such as sinkhole, dolines, swallow holes and fractures (Bono and Percopo 1996).

Pertuso Spring reacts very fastly to precipitation events, with significant increases in discharge rates, which are proportional to the intensity of rainfalls. Groundwater coming from Pertuso Spring is collected within an aquifer mostly made by a well-known volume of carbonate rocks (White 2002). The most distinctive feature of Pertuso karst spring is the branching network of conduits that increases in size in the downstream direction (Fig.2). The largest active conduit drains the groundwater flow coming from the surrounding aquifer matrix, the adjoining fractures and the smaller nearby conduits (White and White 1989). This conduit network is able to rapidly discharge large quantities of water through this karst aquifer (up to $3 \mathrm{~m}^{3} / \mathrm{s}$ ).

Tab. 1 - Main karst springs of Upper Valley of Aniene River (ACEA ATO 2 S.p.A., unpublished data, 2005).

Tab. 1 - Principali sorgenti carsiche dell'Alta Valle dell'Aniene (ACEA ATO 2 S.p.A., dati non pubblicati, 2005).

\begin{tabular}{|l|c|c|}
\hline \multicolumn{1}{|c|}{ Spring } & Altitude (m a.s.l.) & Average discharge (L/s) \\
\hline Acqua Santa & 900 & 65 \\
\hline Acqua Nera & 1030 & 80 \\
\hline Fonte del Forno & 950 & 164 \\
\hline Cesa degli Angeli & 940 & 200 \\
\hline Radica & 1110 & 250 \\
\hline Pertuso & 698 & 1400 \\
\hline
\end{tabular}

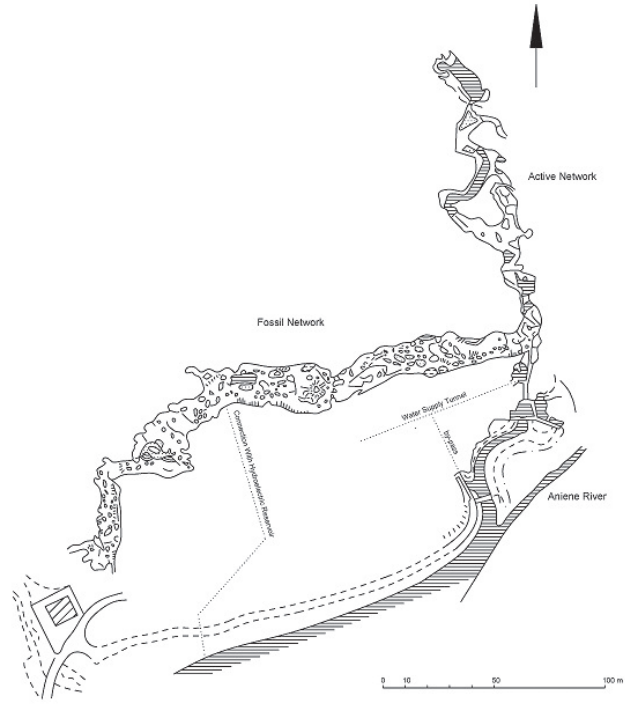

Fig. 2 - Plan view of the development of Pertuso Spring karst drainage network (modified from ACEA ATO 2 S.p.A., unpublished data, 2005).

Fig. 2 - Sviluppo planimetrico della rete carsica della Sorgente Pertuso (modificata da ACEA ATO 2 S.p.A., dati non pubblicati, 2005).

\section{Materials and Methods}

This paper presents part of the results of more than one year of monitoring of the Environmental Monitoring Plan, related to the catchment project of the Pertuso Spring. Water samples have been collected from three sampling points within the study area, i.e. one from Pertuso Spring, the others from two gauging stations located along the Aniene River, respectively, upstream (SW_01) and downstream (SW_02) the spring (Fig.1). These gauging stations belong to the monitoring network set up for the Environmental Monitoring Plan in agreement with the Ministerial Decree 260/2010, chosen to focus on the sensitive connections between surface water and groundwater (Sappa and Ferranti 2014). According to the Environmental Monitoring Plan, groundwater and surface water have been monitored seasonally (4/year) with the aim of set up the hydrogeological conceptual model of the karst aquifer (Sappa and Ferranti 2014).

The experimental data, referred to the period July 2014 - December 2015, were obtained from field investigations and from chemical laboratory analyses. Water temperature, electrical conductivity and $\mathrm{pH}$ values were determined in field using HANNA HI9813-6 waterproof hand-held meter (Hanna Instruments, Woonsocket, RI, USA). Geochemical analyses were carried out at the Geochemical Laboratory of Sapienza University of Rome. Water samples were filtered through cellulose filters $(0.45 \mu \mathrm{m})$, and their major and minor constituents were determined by ion chromatography (IC) by a 761 professional IC Metrohm (reliability $\pm 2 \%$ ) (Metrohm, Herisau, Switzerland). Bicarbonate $\left(\mathrm{HCO}_{3}^{-}\right)$was determined by titration with $0.1 \mathrm{~N} \mathrm{HCl}$ (reliability $\pm 2 \%$ ). A statistical summary of the major physicochemical parameters is shown in Tab.2.

The geochemical modeling program PHREEQC, version 3.0 (Parkhurst and Appello 1999), implemented with the 
Tab. 2 - Summary statistics for in situ measurements of physicochemical parameters and chemical concentrations of constituents of water samples (ions in mg/L, electrical conductivity in $\mu \mathrm{S} / \mathrm{cm}$, $\mathrm{T}$ in ${ }^{\circ} \mathrm{C}$, hardness in ${ }^{\circ} \mathrm{F}$ ).

Tab. 2 - . Statistica riassuntiva dei parametri fisico-chimici misurati in situ e delle concentrazioni chimiche dei campioni d'acqua (ioni in $\mathrm{mg} / \mathrm{L}$, conduttanza elettrica in $\mu \mathrm{S} / \mathrm{cm}, \mathrm{T}$ in ${ }^{\circ} \mathrm{C}$, durezza in ${ }^{\circ} \mathrm{F}$ ).

\begin{tabular}{|l|c|c|c|c|c|c|c|c|c|}
\hline \multirow{2}{*}{ Parameters } & \multicolumn{3}{|c|}{ SW_01 } & \multicolumn{3}{c|}{ Pertuso spring } & \multicolumn{3}{c|}{ SW_02 } \\
\cline { 2 - 12 } & Min & Max & Mean & Min & Max & Mean & Min & Max & Mean \\
\hline $\mathrm{Ca}^{2+}$ & 53.4 & 57.8 & 55.0 & 48.9 & 53.3 & 50.8 & 51.3 & 55.6 & 52.7 \\
\hline $\mathrm{Mg}^{2+}$ & 23.6 & 25.2 & 24.4 & 8.3 & 10.4 & 9.5 & 12.0 & 14.7 & 12.9 \\
\hline $\mathrm{Na}^{+}$ & 2.3 & 2.6 & 2.4 & 1.8 & 2.0 & 1.9 & 2.0 & 2.3 & 2.1 \\
\hline $\mathrm{K}^{+}$ & 0.4 & 0.5 & 0.4 & 0.3 & 0.5 & 0.4 & 0.3 & 0.7 & 0.43 \\
\hline $\mathrm{HCO}_{3}^{-}$ & 281.8 & 302.6 & 290.6 & 206.0 & 238.0 & 218.8 & 218.4 & 235.5 & 225.7 \\
\hline $\mathrm{SO}_{4}{ }^{2-}$ & 2.9 & 3.2 & 3.0 & 2.3 & 2.5 & 2.4 & 2.5 & 2.7 & 2.6 \\
\hline $\mathrm{Cl}^{-}$ & 3.8 & 4.5 & 4.2 & 3.3 & 3.7 & 3.5 & 3.3 & 4.2 & 3.7 \\
\hline $\mathrm{NO}_{3}{ }^{-}$ & 0.8 & 1.3 & 1.1 & 0.9 & 1.2 & 1.0 & 0.9 & 1.1 & 1.0 \\
\hline $\mathrm{T}$ & 5.8 & 11.3 & 8.56 & 8.0 & 9.5 & 8.5 & 6.7 & 10.7 & 8.3 \\
\hline $\mathrm{pH}$ & 8.0 & 8.5 & 8.4 & 7.8 & 8.0 & 7.9 & 8.1 & 8.2 & 8.2 \\
\hline $\mathrm{EC}$ & 356.0 & 395.0 & 384.4 & 283.0 & 291.0 & 288.0 & 294.0 & 317.0 & 310.2 \\
\hline $\mathrm{Hardness}$ & 23.1 & 24.8 & 23.8 & 16.1 & 17.4 & 16.6 & 17.9 & 19.3 & 18.5 \\
\hline
\end{tabular}

thermodynamic dataset wateq4f.dat, was employed to assess the state of equilibrium among groundwater, surface water and carbonate minerals present in terms of saturation index. The saturation index (SI) indicates the chemical equilibrium potential between water and minerals and the tendency for water-rock interaction (Wen et al. 2008). Negative values of SI highlight that water samples are undersaturated with respect to a particular mineral, indicating the possibility of mineral phase dissolution by groundwater and, thus, a potential source of constituents. Likewise, $\mathrm{SI}>0$ reflects the oversaturated state, showing the possibility of mineral phase precipitation, thus limiting the constituent concentration. $\mathrm{SI}=0$ represents the mineral phase equilibrium state. The discharge measurements were carried out along the Aniene River, upstream (SW_01) and downstream (SW_02) Pertuso Spring, by the application of traditional current meter. According to the U.S. Geological Survey (USGS) procedure, stream discharge has been calculated as the product of the cross section area by the average stream flow velocity in the cross section obtained using a current meter (US EPA Region 6 2003, BS EN ISO 2007). The main equipment needed to measure the stream flow velocity is a SEBA horizontal axis current meter F1 (SEBA Hydrometrie GmbH \& Co. KG, Kaufbeuren, Germany), having a propeller diameter of 80 $\mathrm{mm}$ which, combined with SEBA Z6 pulse counter, allows to measure velocity between $0.025 \mathrm{~m} / \mathrm{s}$ and $10 \mathrm{~m} / \mathrm{s}$. The SEBA current meter has been used according to EN ISO 748:2007 requirements (BS EN ISO 2007). This current meter method gives the local water velocity in each vertical following the application of a calibration equation between stream velocity, $\mathrm{v}(\mathrm{cm} / \mathrm{s})$ and the number of spins, $\mathrm{n}(\mathrm{s}-1)(1)$.

$$
v=0.82+33.32 n
$$

\section{Results and Discussion}

In order to establish the groundwater discharge pattern, hydrochemical data and discharge measurements were used in this study. $\mathrm{Ca}^{2+}, \mathrm{Mg}^{2+}$ and $\mathrm{HCO}_{3}{ }^{-}$represent more than $80 \%$ of the dissolved solids in water samples and these concentrations are influenced by the dissolution of carbonate minerals, forming limestone, which are the most dominant formations outcropping in the study area. The hydrochemical facies of groundwater and surface water were studied by plotting the concentrations of major cations and anions in the Piper trilinear diagram (Fig.3) (Piper 1944).

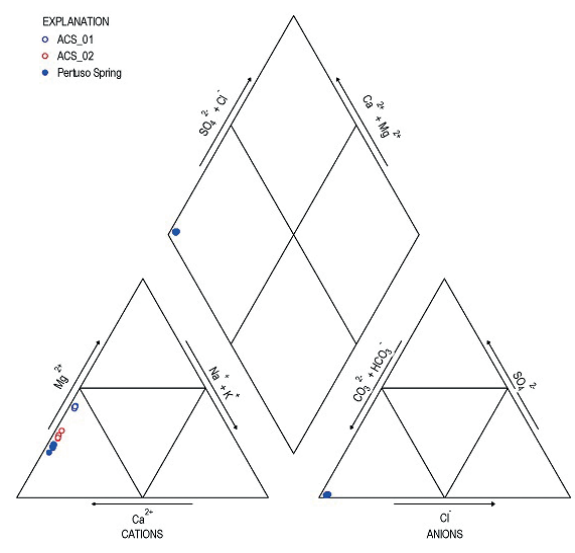

Fig. 3 - Piper plot for hydrochemical facies classification of groundwater and surface water.

Fig. 3 - Diagramma di Piper per la classificazione in facies idrochimiche delle acque sotterranee e superficiali.

Based on the dominance of major cationic and anionic species two hydrochemical facies have been identified: i) Ca$\mathrm{Mg}-\mathrm{HCO}_{3}$ and ii) $\mathrm{Ca}-\mathrm{HCO}_{3}$. These results are due to the presence of limestone, dolomitic limestones and dolomites outcropping in the study area. Water samples coming from SW_01 gauging station present higher values of concentration in $\mathrm{Mg}^{2+}$, while those coming from Pertuso Spring are definitely poorer in it, and show a clear composition of Ca$\mathrm{HCO} 3$ water type (Fig.3). The different hydrochemical facies between groundwater and surface water are visible in 
the high concentration of $\mathrm{Mg}^{2+}$ in the Aniene River. These hydrochemical facies highlight that carbonate weathering processes (e.g. calcite and dolomite) are the most important factors of the observed water type.

Thus, the scatter plot of $\left(\mathrm{Ca}^{2+}+\mathrm{Mg}^{2+}\right)$ versus $\left(\mathrm{SO}_{4}{ }^{2-}+\mathrm{HCO}_{3}{ }^{-}\right)$ was prepared to identify the ionic exchange and weathering processes (Fig.4). As shown in Fig.4, all surface water samples are close to the 1:1 equiline suggesting that those ions have resulted from weathering of carbonates. However, water samples from Pertuso Spring are clustered under the 1:1 line indicating ion exchange.

To study the difference in $\mathrm{Mg}^{2+}$ content between groundwater and surface water, a ternary diagram of cations $\left(\mathrm{Ca}^{2+}, \mathrm{Mg}^{2+}\right.$ and $\mathrm{Na}^{+}+\mathrm{K}^{+}$) (Edmunds et al. 1987) was used to highlight how the weathering type processes influence the enrichment in Magnesium (Fig.5).

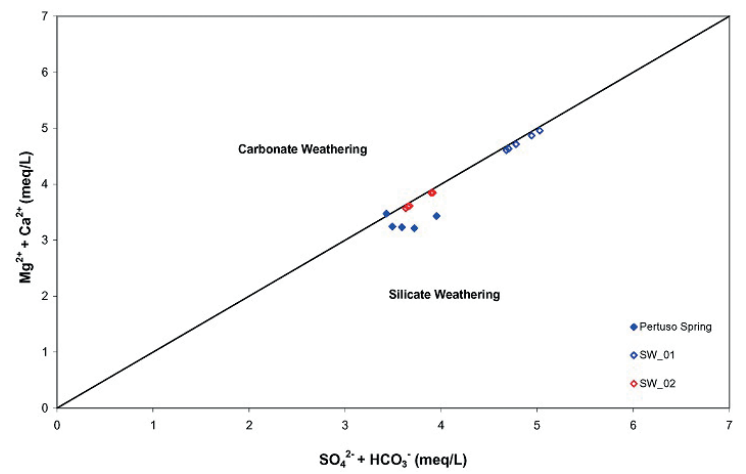

Fig. 4 - Scatter diagram of $\left(\mathrm{Ca}^{2+}+\mathrm{Mg}^{2+}\right)$ versus $\left(\mathrm{SO}_{4}^{2-}+\mathrm{HCO}_{3}^{-}\right)$.

Fig. 4 - Diagramma a dispersione di $\left(\mathrm{Ca}^{2+}+\mathrm{Mg}^{2+}\right)$ versus $\left(\mathrm{SO}_{4}{ }^{2-}+\mathrm{HCO}_{3}{ }^{-}\right)$.

As shown in Fig.5 all samples are placed along the $\mathrm{Ca}^{2+}$ $\mathrm{Mg}^{2+}$ side of the diagram, these groundwater samples are very poor in $\mathrm{Na}^{+}$and $\mathrm{K}^{+}$. The higher $\mathrm{Mg}^{2+}$ concentrations in SW_01 water samples suggest an increase in residence time and depend on the dissolution/precipitation reactions of calcite and dolomite, which occur in the aquifer.

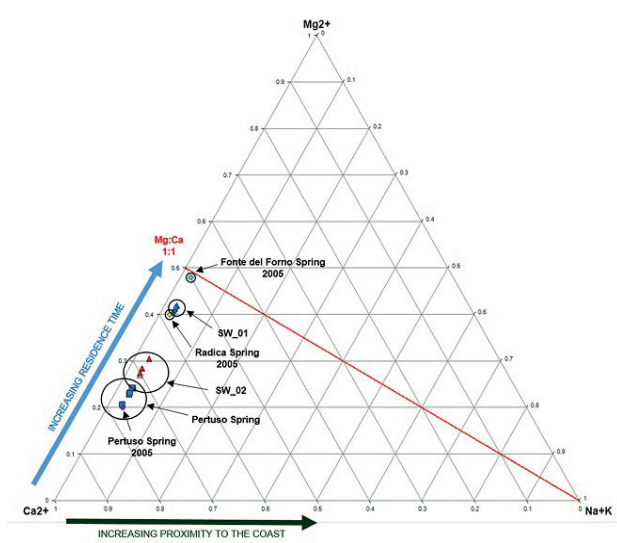

Fig. 5 - Ternary diagram of cations $\mathrm{Ca}^{2+}, \mathrm{Mg}^{2+}$ and $\mathrm{Na}^{+}+\mathrm{K}^{+}$. Relative concentrations of dissolved major cations compared with the composition of local groundwater.

Fig. 5 - Diagramma ternario dei cationi $\mathrm{Ca}^{2+}, \mathrm{Mg}^{2+}$ and $\mathrm{Na}^{+}+\mathrm{K}^{+}$. Concentrazioni relative dei principali cationi disciolti in confronto alla composizione delle acque sotterranee locali.

Based on previous studies [ACEA ATO 2 S.p.A., unpublished data (2005)] similar results have been obtained for other springs located in the upper part of Aniene River coming out in the Triassic dolomite outcropping close to the Pertuso Spring basin (Fig.6).

This hydrochemical characterization leads to a groundwater flow pattern in which two main recharge areas are defined: the first one in the Cretaceous limestone, feeding the Pertuso Spring groundwater; the second one in the Triassic dolomite, feeding the surface water upstream the spring. Saturation indexes calculated with respect to calcite and dolomite of Pertuso Spring and surface water are shown in Figs. 7 and 8. All surface water samples are saturated with respect to calcite (Fig. 7) and dolomite (Fig. 8), while all Pertuso Spring samples are saturated with respect to calcite and undersaturated with respect to dolomite. The saturation with respect to calcite and dolomite reflects a great dissolution and strong mineralization along groundwater flowpaths. The scatter plots diagram for $\mathrm{Mg}^{2+} / \mathrm{Ca}^{2+}$ ratio (Fig. 9) shows that the

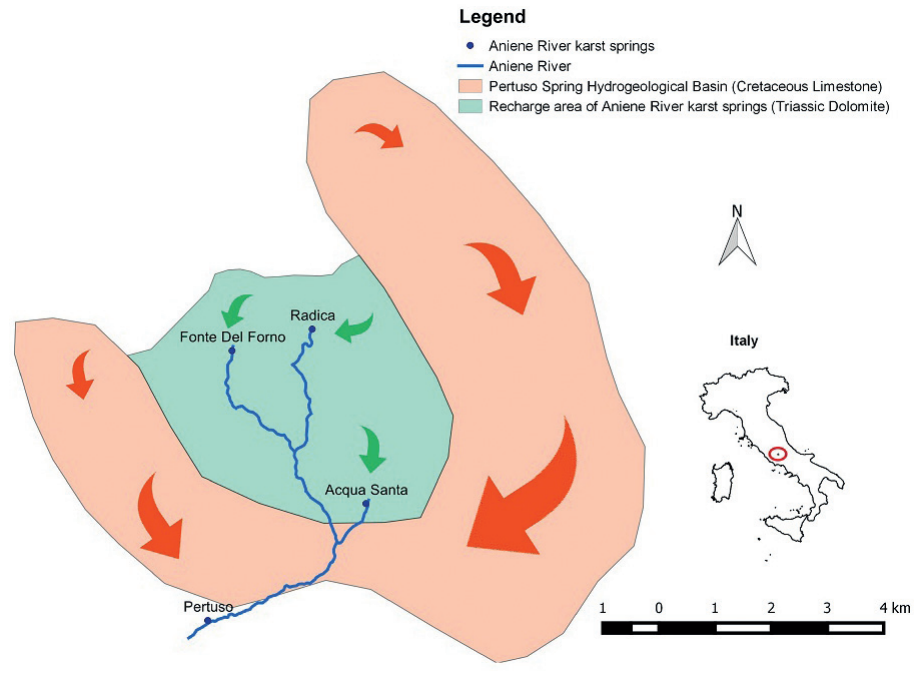

Fig. 6 - Recharge areas of the main karst springs in the Upper Valley of Aniene river.

Fig. 6 - Aree di ricarica delle principali sorgenti carsiche nell'Alta Valle dell'Aniene. 
increase in $\mathrm{Mg}^{2+}$ concentrations in surface water, upstream the Pertuso Spring, and consequently $\mathrm{Mg}^{2+} / \mathrm{Ca}^{2+}$ ratio may be due to the weathering of $\mathrm{Mg}$-rich Triassic dolomites, where dolomitic limestones and dolomites are the most outcropping formations in this area.

As regards Pertuso Spring groundwater, the high $\mathrm{Mg}^{2+}$ / $\mathrm{Ca}^{2+}$ ratios ( 0.5) mainly depend on the residence of water in the karst system, highlighting long residence time and enhanced weathering along the groundwater flowpaths of low-Mg calcite. As a consequence of these properties, water samples taken downstream Pertuso Spring (SW_02) present chemical composition typical of mixing of these two different kinds of waters (Fig. 9).

As a matter of fact, the highest $\mathrm{Mg}^{2+} / \mathrm{Ca}^{2+}$ ratio has been recorded in water samples coming from dolomite rock masses (SW_01 0.7), with medium value at SW_02 gauging station $(\sim 0.4)$. On the other hand, the lowest value of this ratio in groundwater has been observed in Cretaceous limestone area $(\sim 0.3)$ (Tab.3).

Aniene River discharge was measured during the hydrological year 2014-2015, in order to cover the range of seasonal conditions characteristics of this complex hydrogeological system. Measurements by current meter were carried on in two gauging stations located upstream (SW_01) and downstream (SW_02) Pertuso Spring (Tab.4).

Tab.5 shows discharge values recorded in SW_01 and SW_02 gauging stations all over the hydrological year. It can be noticed that the average discharge value referred to SW_01 gauging station can be easily compared with the total average discharge coming from the most important karst springs outcropping in the Upper Part of Aniene River (Tab.1). Thus, the source of $\mathrm{Mg}^{2+}$ concentration values in Aniene River upstream Pertuso Spring (SW_01) is the dissolution of Magnesium rich minerals in Triassic dolomites, sited in the north-east part of the Pertuso Spring basin. Along the Aniene River, this decrease in $\mathrm{Mg}^{2+}$ concentration values is related to an increase in stream flow discharge. SW_02 surface water is the product of the confluence of groundwater coming from Pertuso Spring into the Aniene River (SW_01). As a matter of fact, Aniene River water, which is characterized by water with higher Magnesium concentration values, is affected in its chemical composition by Pertuso Spring groundwater inflowing, and this influence can be measured by $\mathrm{Mg}^{2+}$ concentration values variability along the river downstream. The karst aquifer system has been studied in order to evaluate factors which modify the Aniene River flow due to groundwater-surface water interactions.

The main inputs are the discharge measurements $\left(Q_{1}\right)$ and the $\mathrm{Mg}^{2+}$ concentrations $\left(\mathrm{C}_{1}\right)$ recorded upstream the spring (SW_01). The secondary inputs are the discharge rate $\left(Q_{p}\right)$ and the $\mathrm{Mg}^{2+}$ concentrations $\left(\mathrm{C}_{\mathrm{P}}\right)$ recorded at Pertuso Spring. The main output is the Aniene River discharge $\left(Q_{2}\right)$ and the $\mathrm{Mg}^{2+}$ concentrations $\left(\mathrm{C}_{2}\right)$ recorded at the SW_02 gauging station located downstream Pertuso Spring.

The area under study belongs to a special protected area in the Natural Park of Simbruini Mountains, where all the

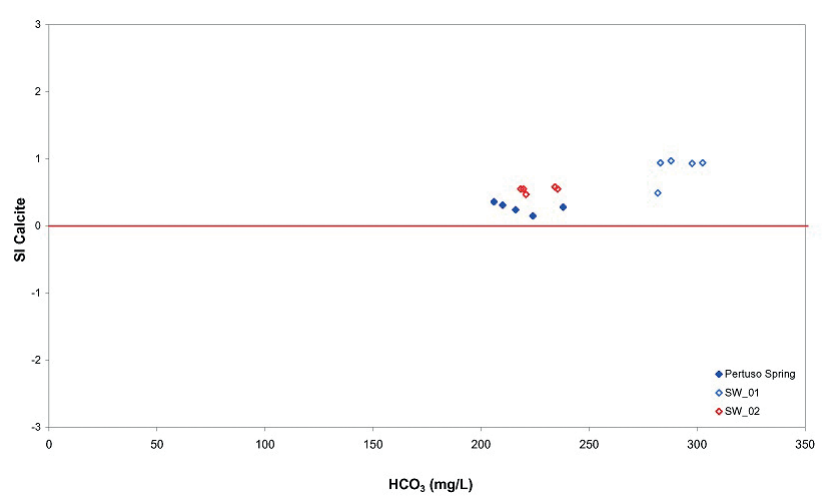

Fig. 7 - Saturation indexes of Calcite of groundwater and surface water.

Fig. 7 - Indice di saturazione in calcite delle acque sotterranee e superficiali.

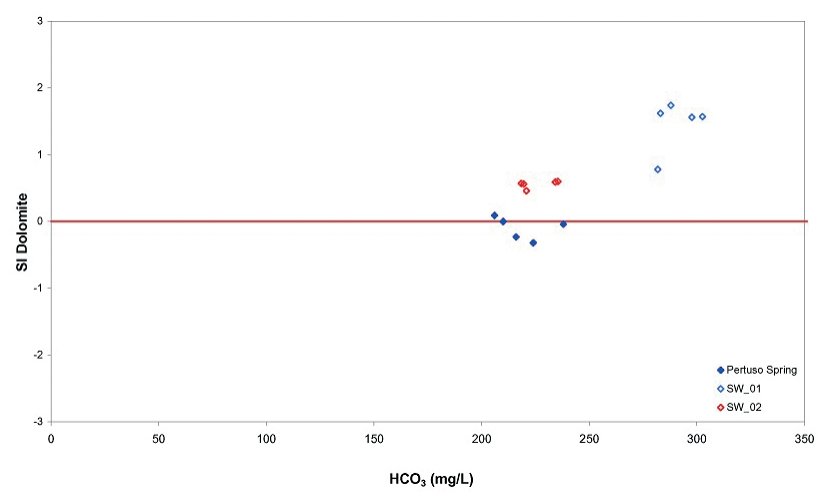

Fig. 8 - Saturation indexes of Dolomite of groundwater and surface water.

Fig. 8 - Indice di saturazione in dolomite delle acque sotterranee e superficiali.

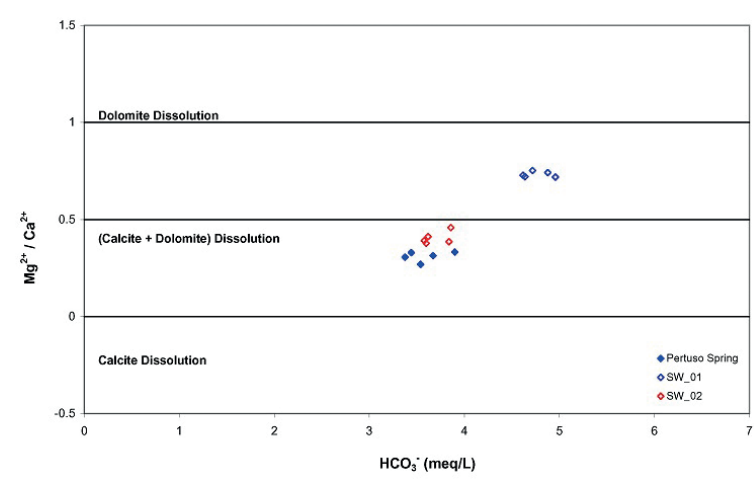

Fig. $9-\mathrm{Mg}^{2+} / \mathrm{Ca}^{2+}$ ratio versus $\mathrm{HCO}_{3}{ }^{-}$in groundwater and surface water.

Fig. $9-\mathrm{Mg}^{2+} / \mathrm{Ca}^{2+}$ ratio versus $\mathrm{HCO}_{3}{ }^{-}$nelle acque sotterranee e superficiali.

Tab. $3-\mathrm{Mg}^{2+} / \mathrm{Ca}^{2+}$ ratio from Pertuso Spring and Aniene River gauging station.

Tab. 3 - Rapporto $\mathrm{Mg}^{2+} / \mathrm{Ca}^{2+}$ della sorgente Pertuso e delle sezioni di misura del Fiume Aniene.

\begin{tabular}{|l|c|r|r|}
\hline $\mathrm{Mg}^{2+} / \mathrm{Ca}^{2+}$ & Pertuso Spring & SW_01 & SW_02 \\
\hline July 2014 & 0.328 & 0.728 & 0.410 \\
\hline November 2014 & 0.267 & 0.669 & 0.357 \\
\hline January 2015 & 0.305 & 0.718 & 0.386 \\
\hline May 2015 & 0.314 & 0.752 & 0.391 \\
\hline December 2015 & 0.332 & 0.741 & 0.458 \\
\hline
\end{tabular}


Tab. 4 - Mean discharge values obtain by current meter metbod, upstream (SW_01) and downstream (SW_02) Pertuso Spring.

Tab. 4 - Valori della portata media ottenuti con il metodo correntometrico, a monte (SW_01) e a valle (SW_02) della sorgente Pertuso.

\begin{tabular}{|l|r|r|}
\hline $\mathbf{Q}\left(\mathrm{m}^{3} / \mathbf{s}\right)$ & SW_01 & SW_02 \\
\hline July 2014 & 0.540 & 2.450 \\
\hline November 2014 & 0.350 & 1.480 \\
\hline January 2015 & 0.410 & 1.920 \\
\hline May 2015 & 0.501 & 2.747 \\
\hline December 2015 & 0.278 & 0.931 \\
\hline
\end{tabular}

anthropic activities are restricted and controlled. On the basis of this hypothesis we have assumed that this system could be considered closed. Thus, the SW_02 gauging station discharge values, come from the contribution of Pertuso Spring discharge $\left(\mathrm{Q}_{\mathrm{p}}\right)$ to the original $\mathrm{SW}$ _01 discharge value, can be represented by (2):

$$
Q_{2}=Q_{1}+Q_{P}
$$

Applying the conservation of mass equation to this closed system, it means (3):

$$
Q_{1} C_{1}+Q_{P} C_{P}=Q_{2} C_{2}
$$

The $\mathrm{n}$ parameter (Tab.5), i.e. the percentage of Pertuso Spring groundwater contribution to total discharge measured at SW_02 is defined according to (4).

$$
n=\frac{Q_{P}}{Q_{2}}=\frac{\left(C_{2}-C_{1}\right)}{\left(C_{P}-C_{1}\right)}
$$

Tab. 5 - Values as percentage contribution of Pertuso Spring groundwater to total discharge measured at the SW_O2 gauging station.

Tab. 5 - Valori del parametro n come contributo percentuale fornito dalle acque sotterranee della sorgente Pertuso alla portata complessiva misurata nella sezione di misura SW_02.

\begin{tabular}{|l|c|c|}
\hline Date & $\mathbf{n}$ & $\mathbf{n}(\%)$ \\
\hline July 2014 & 0.780 & 78.0 \\
\hline November 2014 & 0.752 & 75.2 \\
\hline January 2015 & 0.794 & 79.4 \\
\hline May 2015 & 0.812 & 81.2 \\
\hline December 2015 & 0.709 & 70.9 \\
\hline
\end{tabular}

Tab. 6 - Magnesium content and discharge values obtained by current-meter and Magnesium tracer method ( $Q^{*}$ : discharge values obtained by current meter method; $Q^{* *}$ : discharge values obtained by the difference between the values measured with the current meter in SW_01 and SW_02).

\begin{tabular}{|c|c|c|c|c|c|c|c|c|}
\hline \multirow{2}{*}{ Date } & \multicolumn{2}{|c|}{ SW_01 } & \multicolumn{3}{|c|}{ Pertuso Spring } & \multicolumn{3}{|c|}{ SW_02 } \\
\hline & $\mathrm{Q}^{*}\left(\mathrm{~m}^{3} / \mathrm{s}\right)$ & $\mathrm{Mg}^{2+}(\mathrm{meq} / \mathrm{L})$ & $\mathrm{Q}^{* *}\left(\mathrm{~m}^{3} / \mathrm{s}\right)$ & $\mathrm{Q}_{\mathrm{Mg}}\left(\mathrm{m}^{3} / \mathrm{s}\right)$ & $\mathrm{Mg}^{2+}(\mathrm{meq} / \mathrm{L})$ & $\mathrm{Q}^{*}\left(\mathrm{~m}^{3} / \mathrm{s}\right)$ & $\mathrm{Q}_{\mathrm{Mg}}\left(\mathrm{m}^{3} / \mathrm{s}\right)$ & $\mathrm{Mg}^{2+}(\mathrm{meq} / \mathrm{L})$ \\
\hline July 2014 & 0.54 & 1.94 & 1.91 & 1.92 & 0.80 & 2.45 & 2.46 & 1.05 \\
\hline November 2014 & 0.35 & 1.93 & 1.13 & 1.06 & 0.68 & 1.48 & 1.41 & 0.99 \\
\hline January 2015 & 0.41 & 2.07 & 1.51 & 1.58 & 0.81 & 1.92 & 1.99 & 1.07 \\
\hline May 2015 & 0.50 & 2.02 & 2.23 & 2.16 & 0.77 & 2.75 & 2.66 & 1.00 \\
\hline December 2015 & 0.28 & 2.07 & 0.67 & 0.68 & 0.86 & 0.93 & 0.96 & 1.21 \\
\hline
\end{tabular}

Tab. 6 - Tenore di magnesio e valori di portata attenuti con il metodo correntometrico $\left(\mathrm{Q}^{*}\right.$ : valori di portata attenuti con il metodo correntometrico; $\mathrm{Q}^{* *}$ : valori di portata attenuti come differenza tra I valori misurati con il metodo correntometrico nelle sezioni SW_01 e SW_02). 


\section{Conclusions}

This paper dealt with the assessment of the interactions between karst aquifers feeding Pertuso Spring and Aniene River surface waters on the basis of stream discharge measurements and water geochemical tracers data. The aim was to set up an inverse model, which allowed estimating groundwater flow coming out from Pertuso Spring, starting from surface water discharge measurements and geochemical waters characterization. These preliminary results, obtained in area under study, sited in the karst aquifer outcropping in the Upper Valley of Aniene River, show that it is possible to have a reliable evaluation of Pertuso Spring discharge, through the elaboration of surface water discharge measurements and $\mathrm{Mg}^{2+}$ concentration values, determined both for groundwater, coming from Pertuso Spring, both for surface water sample, collected upstream and downstream Pertuso Spring, along the Aniene River. Although it is subject to some uncertainties, the $\mathrm{Mg}^{2+}$ concentration, as an environmental tracer, provides an indirect method for discharge evaluation of Pertuso Spring due to the mixing of surface water and groundwater, and it provides information o $\mathrm{n}$ changes in water quantity and quality.

\section{REFERENCES}

Bakalowicz M (2005) Karst groundwater: a challenge for new resources. Hydrogeology Journal 13:148-160.

Batiot C, Emblanch C, Blavoux B (2003) Total Organic Carbon (TOC) and magnesium $(\mathrm{Mg} 2+)$ : two complementary tracers of residence time in karstic systems. Comptes Rendus Geoscience 35:205-214.

Bono P, Percopo C (1996) Flow dynamics and erosion rate of a representative karst basin (Upper Aniene River, Central Italy). Environmental Geology 27(3):210-218.

Cherubini C, Pastore N, Francani V (2008) Different approaches for the characterization of a fractured karst aquifer. WSEAS Transactions on fluid mechanics 3:29-35.

Cipollari F, Cosentino D, Parrotto M (1995) Modello cinematico-strutturale dell'Italia centrale "Kinematic model-structural of Central Italy". Studi Geol Camerti 2:135-143.

Clark ID, Fritz P (1997) Environmental isotopes in hydrogeology. CRC Press Inc., Boca Raton, FL, USA.

Damiani AV (1990) Studi sulla piattaforma carbonatica laziale-abruzzese. Nota I. Considerazioni e problematiche sull'assetto tettonico e sulla paleogeologia dei Monti Simbruini, "Studies on the LazioAbruzzi carbonate platform. Note XI. Considerations and problems on tectonic and paleogeologic Simbruini Mts." Memorie descrittive Carta Geologica d'Italia 38:177-206.

Edmunds WM, Cook JM, Darling WG, Kinniburgh DG, Miles DL, Bath AH, Morgan-Jones M and Andrews JN (1987) Baseline geochemical conditions in the Chalk aquifer, Berkshire, UK: a basis for groundwater quality management. Applied Geochemistry 2:251274.

EN ISO 748:2007 (2007) Hydrometry. Measurement of liquid flow in open channels using current-meters or floats. react-text: $55 \mathrm{DOI}$ : 10.1007/BF00770434BS

Foster S, Hirata R, Andreo B (2013) The aquifer pollution vulnerability concept: aid or impediment in promoting groundwater protection. Hydrogeology Journal 21:1389-1392.

Guida M, Guida D, Guadagnuolo D, Cuomo A, Siervo V (2013) Using Radon-222 as a naturally occurring tracer to investigate the streamflow-groundwater interactions in a typical Mediterranean fluvial-karst landscape: the interdisciplinary case study of the Bussento river (Campania region, Southern Italy). WSEAS Transactions on System 12(2):85-104.

Guo Q, Wang Y, Ma T, Li L (2005) Variation of karst springs discharge in recent five decades as an indicator of global climate change: a case study at Shanxi, northern China. Science in China Series D: Earth Science 48(11):2001-2010.

Herman JS, White WB (1985) Dissolution kinetics of dolomite: effects of lithology and fluid flow velocity. Geochimica et Cosmochimica Acta 49:2017-2026.

Hunkeler D, Mudry J (2007) Hydrochemical tracers, in methods in karst hydrogeology. Taylor and Francis, London, UK.

Langmuir D (1971) Geochemistry of some carbonate ground waters in Central Pennsylvania. Geochimica et Cosmochimica Acta 35(10):1023-1045.

Leibundgut C, Maloszewski P, Kulls C (2009) Tracers in hydrology. 1st ed. Wiley-Blackwell, Chichester, UK.

Mazor E (2004) Chemical and isotopic groundwater hydrology. Marcel Dekker, New York, NY, USA.

Mudarra M, Andreo B (2011) Relative importance of the saturated and the unsaturated zones in the hydrogeological functioning of karst aquifers: the case of Alta Cadena (Southern Spain). Journal of Hydrology 397(3-4):263-280.

Parkhurst DL, Appello CAJ (1999) User's guide to PHREEQC (Version 2). A computer program for speciation, batch-reaction, one-dimensional transport, and inverse geochemical calculations. US Geological Survey Water-Resources Investigations Report 99-4259. 
Piper M (1944) A graphic procedure in the geochemical interpretation of water-analyses. Transactions of the American Geophysical Union 25:914-923.

Sappa G, Ferranti F (2014) An integrated approach to the environmental monitoring plan of the Pertuso spring (Upper Valley of Aniene River). Italian Journal of Groundwater 3(136)47-55.

Sappa G, Ferranti F, De Filippi FM (2015a) Environmental tracer approach to discharge evaluation of Pertuso Spring (Italy), Proceedings of the $10^{\text {th }}$ International Conference on Energy \& Environment (EE'15) in Recent Advances on Energy and Environment, edited by Aida Bulucea, WSEAS, pp 54-62.

Sappa G, Ferranti F, Ergul S (2015b) Vulnerability assessment of Mazzoccolo Spring aquifer (Central Italy), combined with geo-chemical and isotope modelling, Engineering Geology for Society and Territory, Vol. 5, Urban Geology, Sustainable Planning and Landscape Exploitation, pp 1387-1392.

Sappa G, Ferranti F, Ergul S, Ioanni G (2013) Evaluation of the groundwater active recharge trend in the coastal plain of Dar es Salaam (Tanzania). Journal of Chemical and Pharmaceutical Research 5(12)548-552.

Tooth AF, Fairchild IJ (2003) Soil and karst aquifer hydrological controls on the geochemical evolution of speleothem-forming drip waters, Crag Cave, southwest Ireland. Journal of Hydrology 273:51-68.

US EPA Region 6 (2003) Standard operating procedure for stream flow measurement.
Ventriglia U (1990) Idrogeologia della Provincia di Roma, IV, Regione orientale "Hydrogeology of the Province of Rome, IV, Eastern region". Amministrazione Provinciale di Roma, Assessorato LL.PP, Viabilità e trasporti, Roma.

Wen XH, Wu YQ, Wu J (2008) Hydrochemical characteristics of groundwater in the Zhangye Basin, North-western China. Environmental geology 55(8):1713-1724.

White WB (1969) Conceptual models for carbonate aquifers. Ground Water 7:15-22.

White WB (1988) Geomorphology and hydrology of karst terrains. Oxford University Press, New York, NY, USA.

White WB (2002) Karst hydrology: recent developments and open questions. Engineering Geology 65:85-105.

White WB, White EL (1989) Karst hydrology-concepts from the Mammoth Cave area. Van Nostrand Reinhold, New York, NY, USA.

Zwahlen F (2004) Vulnerability and risk mapping for the protection of carbonate (karst) aquifers, final report (COST Action 620). European Commission, Directorate-General XII Science, Research and Development, Brussels, Belgium. 